\title{
Article \\ Comparison of Antivirulence Activities of Black Ginseng against Methicillin-Resistant Staphylococcus aureus According to the Number of Repeated Steaming and Drying Cycles
}

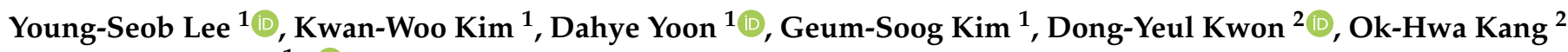 \\ and Dae Young Lee ${ }^{1, *(D)}$ \\ 1 Department of Herbal Crop Research, National Institute of Horticultural and Herbal Science, RDA, \\ Eumseong, Chungbuk 27709, Korea; youngseoblee@korea.kr (Y.-S.L.); swamp1@korea.kr (K.-W.K.); \\ dahyeyoon@korea.kr (D.Y.); kimgs0725@korea.kr (G.-S.K.) \\ 2 Department of Oriental Pharmacy, College of Pharmacy and Wonkwang Oriental Medicines \\ Research Institute, Wonkwang University, Iksan 54538, Korea; sssimi@wku.ac.kr (D.-Y.K.); \\ okey@wku.ac.kr (O.-H.K.) \\ * Correspondence: dylee0809@gmail.com
}

Citation: Lee, Y.-S.; Kim, K.-W.; Yoon, D.; Kim, G.-S.; Kwon, D.-Y.; Kang, O.-H.; Lee, D.Y. Comparison of Antivirulence Activities of Black Ginseng against Methicillin-Resistant Staphylococcus aureus According to the Number of Repeated Steaming and Drying Cycles. Antibiotics 2021, 10 , 617. https://doi.org/10.3390/ antibiotics 10060617

Academic Editors: Jhih-Hang Jiang and Xenia Kostoulias

Received: 19 April 2021

Accepted: 19 May 2021

Published: 21 May 2021

Publisher's Note: MDPI stays neutral with regard to jurisdictional claims in published maps and institutional affiliations.

Copyright: (c) 2021 by the authors. Licensee MDPI, Basel, Switzerland. This article is an open access article distributed under the terms and conditions of the Creative Commons Attribution (CC BY) license (https:/ / creativecommons.org/licenses/by/ $4.0 /)$.

Abstract: Korean ginseng has been widely used in Eastern medicine for thousands of years. The contents of the compounds in ginseng roots change depending on the amount of steaming and drying, and the drying method used. Black ginseng (BG) is the Korean ginseng processed by repeated steaming and drying. In this study, 5-year-old fresh Korean ginseng roots were steamed and dried 3 or 5 times, and we investigated how many cycles of steaming and drying are preferable for antivirulence activities against methicillin-resistant Staphylococcus aureus (MRSA). As a result, the antivirulence activities was increased by the treatment of BG that was steamed and dried three times, and the effect was further increased by five-time processed BG. Moreover, an ELISA showed that the TNF- $\alpha$ production of RAW264.7 cells stimulated by MRSA supernatants was inhibited by subinhibitory concentrations of BG extract. The expression of Hla, staphylococcal enterotoxin A (SEA), and staphylococcal enterotoxin B (SEB), an important virulence factor in the pathogenicity of MRSA, was found to decrease when bacterial cells were treated with BG extract. The antivirulence activities of BG were not simply due to pathogen growth inhibition; the BG extract was shown to decrease agr $A$, hla, sea, and seb expression in MRSA. Therefore, BG strongly reduces the secretion of the virulence factors produced by Staphylococcus aureus, suggesting that a BG-based structure may be used for the development of drugs aimed at staphylococcal virulence-related exoproteins. This study suggests that BG could be used as a promising natural compound in the food and pharmaceutical industry.

Keywords: Staphylococcus aureus; MRSA; black ginseng; Panax ginseng

\section{Introduction}

Staphylococcus aureus (S. aureus) is a common bacterial genus in hospitals and communities found on the anterior nares of 20 to $80 \%$ of the human population [1,2]. Preventing and controlling the spread of the antibiotic resistance of this pathogen requires numerous actions of prevention, and infection control is now essential. The rapid global emergence of resistant pathogenic bacteria that cause fatal infectious diseases such as methicillinresistant $S$. aureus (MRSA) is occurring, endangering the efficacy of antibiotics used in medical institutions $[3,4]$. This pathogen secretes toxins and exoenzymes that exacerbate acute infections such as sepsis, skin abscesses, and food poisoning, and toxins are a means of aggression by harmful bacteria that damage human tissue and cells $[5,6]$.

$\alpha$-Hemolysin ( $\alpha$-toxin, Hla), also known as a-toxin, is a $33 \mathrm{kDa}$ pore-forming protein of a water-soluble monomer that is encoded by a single genetic locus, hla. Hla, which oligomerizes to a prepore structure, assembles into a homoheptamer. Then, Hla penetrates 
the membrane of the target cell by the extrusion of the $\beta$ barrel and forms a hydrophilic transmembrane channel in the lipid bilayer of the membrane. Pore formation causes leakage of molecules smaller than $2 \mathrm{kDa}$, such as $\mathrm{K}^{+}$and $\mathrm{Ca}^{2+}$ ions, inducing the necrotic death of the target cell [7-9]. Staphylococcal enterotoxins (SEs) secreted by S. aureus are bacterial exotoxins that cause staphylococcal food poisoning (SFP) [10]. SEs are lowmolecular-weight (23-29 kDa) single-chain basic globular proteins [11]. SEs affect intestinal cells, which induces gastroenteritis, typically evoking vomiting, diarrhea, and intestinal or gastric inflammation [10,12]. These are also part of the family of superantigens (SAgs) because of their activity leading to the excessive activation of $T$ cells, with a subsequent enormous release of cytokines, invoking a life-threatening toxic-shock syndrome [10]. The most common staphylococcal enterotoxins are staphylococcal enterotoxin A (SEA) and staphylococcal enterotoxin B (SEB) [12]. The accessory gene regulatory (Agr) system controls virulence factor gene expression by sensing the accumulation of autoinducing peptide via response regulator AgrA and histidine kinase AgrC [13]. The Agr locus has a direct positive impact on Hla expression [14].

Recently, antivirulence studies of medicinal plants used as traditional medicines were attempted as a potential source of drugs for managing antibiotic resistance. Medicinal plants are primarily used in traditional medical systems, which for thousands of years have played an important role in resisting various diseases and caring for human health [15]. Some antibacterial components isolated from medicinal plants could have a synergistic effect with antibiotics used in hospitals; in particular, they are a new alternative to the treatment of infectious diseases caused by antibiotic-resistant bacteria [16].

Korean ginseng (Panax ginseng C. A. Meyer) is a valuable medicinal plant belonging to the Panax genus of Araliaceae, and it is well-known for a variety of ginsenosides that show diverse biological activities. Recently, many studies reported ginseng to have multiple medicinal and pharmacological properties, including an influence on the endocrine, immune, and nervous systems, and anticancer, anti-inflammation, and antiaging effects $[17,18]$. The components of ginsenosides are quite different depending on the processing method of Korean ginseng roots, such as dried white ginseng without processing, and processed red ginseng and black ginseng (BG) by special methods such as steam treatment $[17,19]$. Korean ginseng contains dammarane-type ginsenosides and a unique saponin found in the Panax genus that is nontoxic and displays antibacterial activity against nonhemolytic bacteria [20]. Ginsenosides Rb1, Rb2, Rc, Rd, Rg1, and Re, which are major constituents of ginseng, are transformed into less polar ginsenosides $\mathrm{Rg} 3$, $\mathrm{Rg} 5$, Rk1, and F4 according to the processing method [21]. BG is usually developed from fresh or white ginseng steamed several (usually 9) times at $96{ }^{\circ} \mathrm{C}$ for $3 \mathrm{~h}$, followed by hot-air-drying at $50{ }^{\circ} \mathrm{C}$ for $24 \mathrm{~h} \mathrm{[22-25].} \mathrm{While} \mathrm{this} \mathrm{processing} \mathrm{method} \mathrm{has} \mathrm{always} \mathrm{been}$ used in Korea in the processing of Rehmanniae Radix (Rehmannia glutinosa Liboschitz ex Steudel; Scrophulariaceae), it has been rarely used for processing ginseng in ancient Eastern medicine [26,27]. Black ginseng was first prepared in South Korea; then, it became widely used in China and Southeast Asian countries [26]. Previous studies reported that BG exhibits antibacterial, anticarcinogenic, immunomodulatory, anti-inflammatory, hepatoprotective, antidiabetic, antiobesity, antihyperlipidemic, antioxidant, and tonic effects $[17,20,26]$, however, the inhibitory effect of BG on MRSA toxins is not yet clear. In this study, antivirulence activity was compared according to BG processing method (steamed and dried 3 or 5 times, respectively).

\section{Results}

\subsection{Metabolite Profiling of Black Ginseng Products by UPLC-QTOF/MS}

With an extraction method constructed in our previous study [28], UPLC-QTOF/MS was used to profile various metabolites, including ginsenosides, from BG3 and BG5. Methanol $(70 \% v / v)$ was used to extract metabolites from the samples, and then, the extracts were subjected to UPLC-QTOF/MS in the negative ion mode. Figure 1 shows the representative base peak intensity (BPI) chromatograms of diverse metabolites from 
BG3 and BG5, respectively. The intensity of several peaks was different depending on distinct samples. For example, compared to other products, BG5 showed a lower intensity of peaks eluted from 5.56 to $5.84 \mathrm{~min}$ and higher intensity of peaks eluted from 26.25 to $27.76 \mathrm{~min}$ in the BPI chromatogram. These demonstrated that different processing methods changed the metabolic composition of BG. Moreover, this information is necessary for the reproducibility of the work.

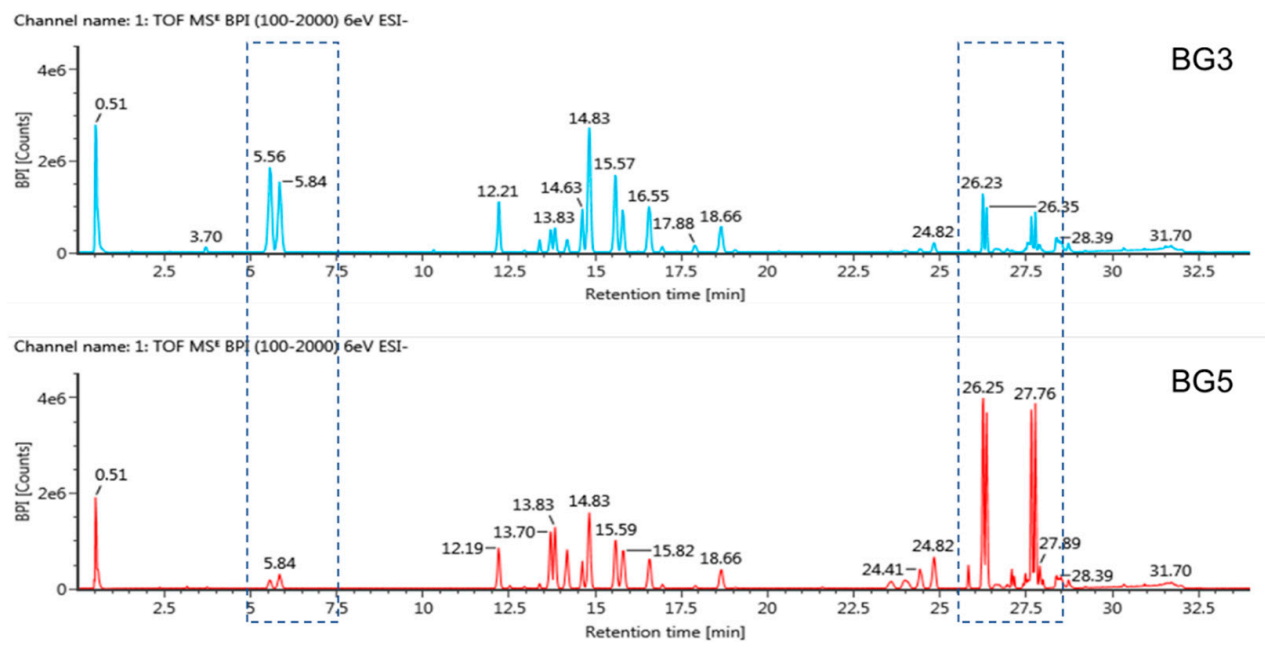

Figure 1. The base peak intensity (BPI) chromatogram of diverse metabolites from BG3 and BG5.

\subsection{Growth Curve Analysis for Methicillin-Resistant Staphylococcus aureus}

The ATCC 33591 was a hospital-associated MRSA (HA-MRSA) standard strain, and USA300 was a wild-type LA County (LAC) strain, community-associated MRSA (CAMRSA) [29]. The USA300 used in this study is resistant to methicillin, and was obtained from the Advanced Radiation Technology Institute, Korea Atomic Energy Research Institute (Jeongeup, South Korea) [30]. The result of the broth minimum inhibitory concentration (MIC) experiment was confirmed to be $4 \mathrm{mg} / \mathrm{mL}$, regardless of the number of steam and drying processes (data not shown). Growth curve analysis treated for $0,4,8,12,16$, 20 , and $24 \mathrm{~h}$ with $1 / 2 \mathrm{MIC}(2 \mathrm{mg} / \mathrm{mL})$ of BG extract also showed no growth inhibition, respectively (Figure 2). These results show that $B G$ does not have high antibacterial activity against MRSA. However, we hypothesized that BG may reduce the ability of $S$. aureus toxins to attack the host; therefore, to investigate this, we tested the effect of BG extract on toxicity-related factors in MRSA.
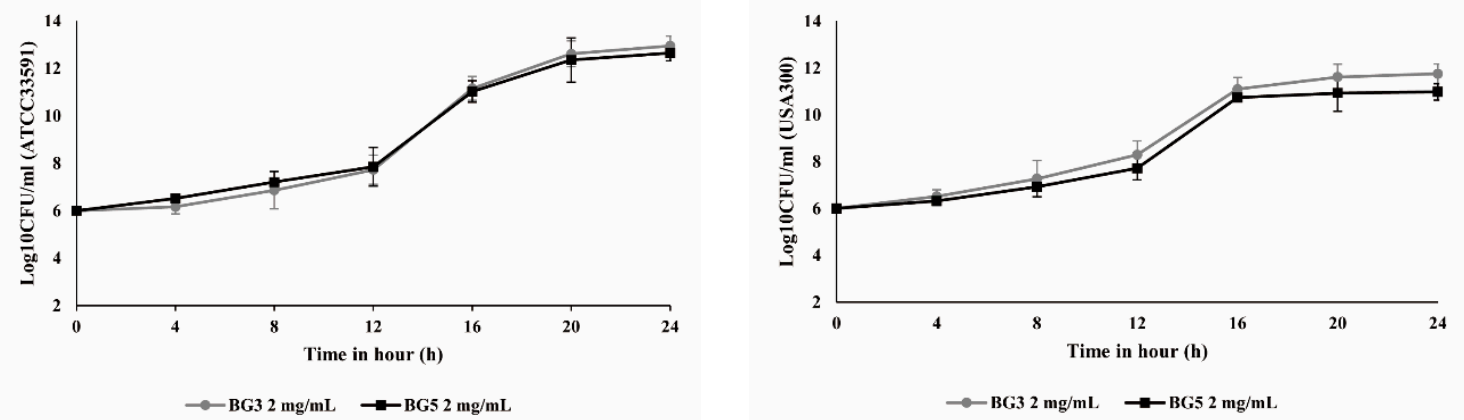

Figure 2. Growth curve for methicillin-resistant Staphylococcus aureus (MRSA) cultured with subinhibitory concentrations of BG3 or BG5. Bacterial suspensions (final density, $1.5 \times 10^{6} \mathrm{CFU} / \mathrm{mL}$ ) were incubated with $2 \mathrm{mg} / \mathrm{mL}$ of BG3 or BG5. At about $4 \mathrm{~h}$ intervals, aliquots $(0.1 \mathrm{~mL})$ of the culture were serially diluted 10 -fold in saline as needed and plated on TS agar, followed by incubation at $37^{\circ} \mathrm{C}$ for $24 \mathrm{~h}$. Colony counts were performed on plates, and 30-300 colonies were enumerated. Each point of each group represents the means \pm standard deviation of three independent experiments, and the variance of each data did not exceed $5 \%$ relative to the mean value. 


\subsection{Inhibition of TNF- $\alpha$ Expression of BG Extracts in RAW 264.7 Cells}

To clarify the biological relevance of the reduction of Staphylococcal exotoxin secretion by BG, we performed a tumor necrosis factor (TNF) release assay. The expression level of TNF- $\alpha$ was measured in RAW 264.7 cells stimulated by MRSA-cultured media [31,32]. Among the virulence factors secreted by $S$. aureus, $\alpha$-toxin is primarily responsible for the hemolytic activity, and enterotoxins are the most important exotoxins that could act as superantigens, stimulating T cells to release proinflammatory cytokines [32,33]. Graded concentrations of BG (1000 and $2000 \mu \mathrm{g} / \mathrm{mL}$ ) were added to the diluted bacterial suspensions. MRSA supernatant without BG treatment was used as a control. After $4 \mathrm{~h}$ incubation, the supernatants $(700 \mu \mathrm{L})$ collected (protein secretion) were filtered through a $0.2 \mu \mathrm{m}$ filter and immediately analyzed. As a result, the expression of TNF- $\alpha$ decreased in cells stimulated by an MRSA culture medium treated with BG extract, and the BG5 extract inhibited more than the BG3 extract did (Figure 3).
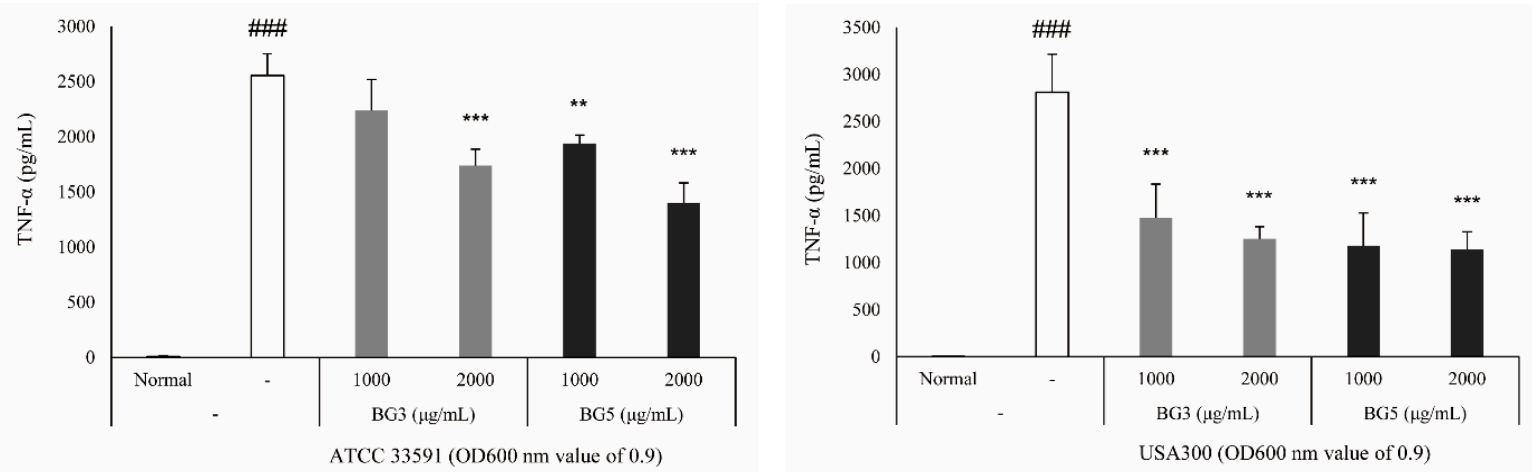

Figure 3. Effect of BG3 and BG5 in TNF- $\alpha$ secretion of 264.7 RAW macrophages stimulated by methicillin-resistant Staphylococcus aureus (MRSA)-cultured media. After stimulation for $16 \mathrm{~h}$ with supernatants of MRSA grown in the presence of graded concentrations of BG3 or BG5 in RAW 264.7 cells, TNF- $\alpha$ levels were measured by enzyme-linked immunosorbent assay (ELISA). Normal group refers to RAW 264.7 cells not treated MRSA-cultured media or BG extracts. Values represent the mean and standard error of three independent experiments. ${ }^{\# \#} p<0.001$ in comparison with normal group. ${ }^{* *} p<0.01$ and ${ }^{* * *} p<0.001$ in comparison with the MRSA group.

\subsection{Inhibitory Effect of BG Extracts in Toxin Expression of S. aureus}

Western blotting was performed to investigate the effect of BG against toxin expression in protein levels. Results showed that MRSA toxins were inhibited by treating with BG. In S. aureus ATCC33591, Hla and SEA were slightly inhibited by treating with BG. However, SEB was significantly inhibited by treating with BG, and BG5 was more effective than BG3 was (Figure 4A). In S. aureus USA300, three toxins were significantly inhibited by treating BG. Hla and SEB were especially decreased more by treating BG5 than by treating BG3. In contrast, SEA was inhibited more by treating BG3 than by treating BG5 (Figure 5A).

\subsection{Inhibitory Effect of BG Extracts on Expression of mRNA-Associated Virulence Factor of MRSA}

It was confirmed by quantitative real-time polymerase chain reaction (qRT-PCR) that antivirulence activities, including on the hla and agrA genes related to Hla in MRSA culture medium, were associated with mRNA reduction by BG extract. The expression of the four genes ( $h l a$, sea, seb, and agrA) was significantly suppressed in S. aureus ATCC 33591 and USA300 by the treatment of BG extracts. The $16 \mathrm{~S}$ ribosome RNA (rRNA) was used as a reference gene. In S. aureus ATCC 33591, it was confirmed that the inhibitory effect of BG5 extract was greater than that of BG3 extract against virulence-related gene expressions (Figure 4B-E). In S. aureus USA300, both BG3 and BG5 showed high inhibitory effects on the hla and agr $A$ genes. In the expression of sea and seb genes, the concentration of $2 \mathrm{mg} / \mathrm{mL}$ of BG3 extract showed the best inhibitory effect (Figure 5B-E). 

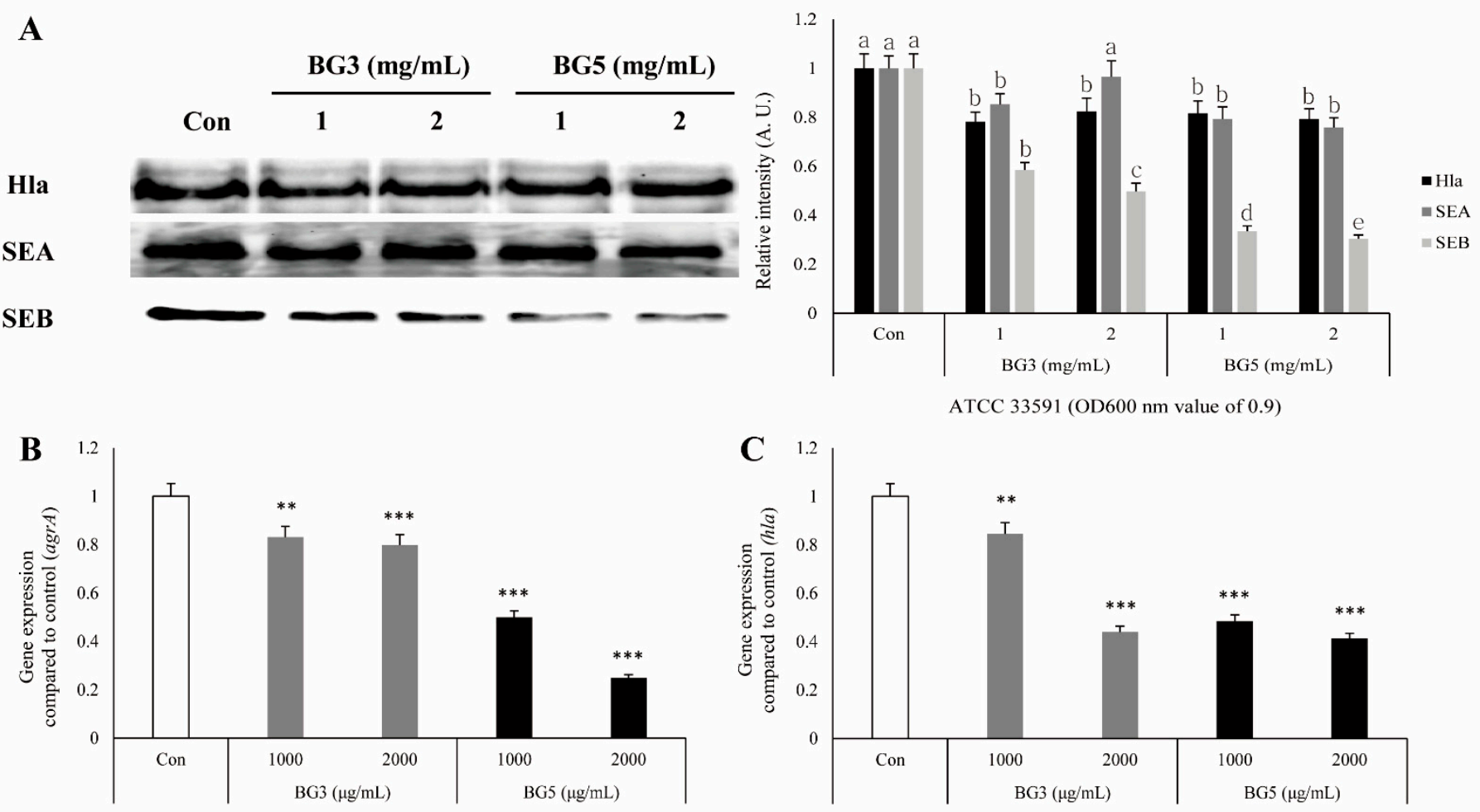

ATCC 33591 (OD600 nm value of 0.9)

ATCC 33591 (OD600 $\mathrm{nm}$ value of 0.9)
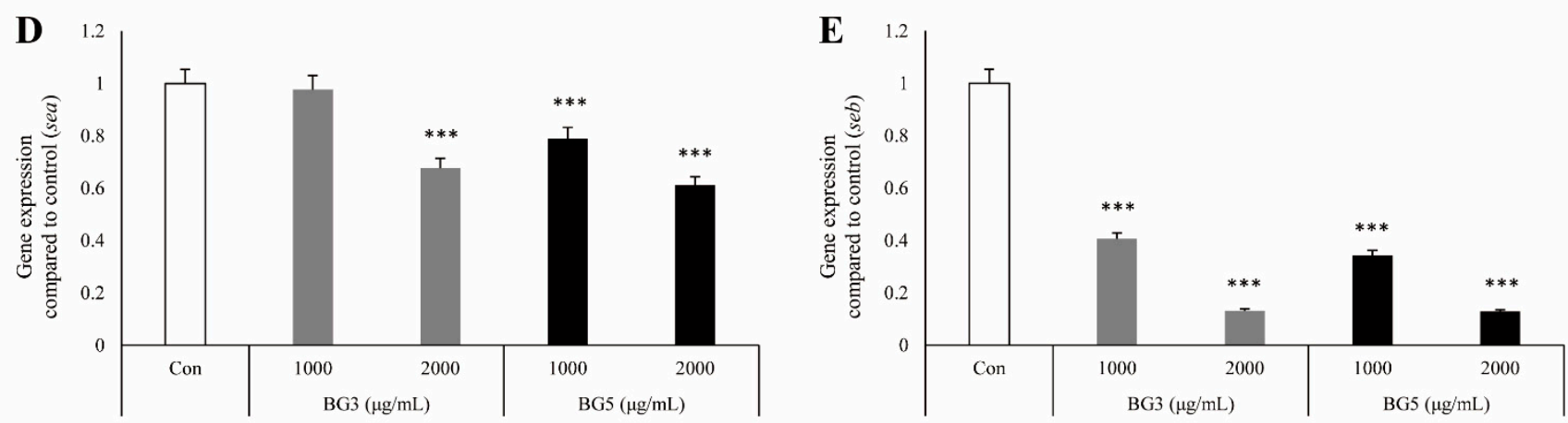

ATCC 33591 (OD600 nm value of 0.9)

ATCC 33591 (OD600 nm value of 0.9)

Figure 4. (A) Inhibitory effects of BG3 and BG5 on the expression of toxic proteins including $\alpha$-hemolysin (Hla), staphylococcal enterotoxin A (SEA), and staphylococcal enterotoxin B (SEB) in S. aureus ATCC33591, as analyzed by Western blotting. S. aureus ATCC 33591 cells treated with serial dilutions of BG3 or BG5 (1 and $2 \mathrm{mg} / \mathrm{mL}$ ) for $4 \mathrm{~h}$. (a-e) Significant differences at $p<0.05$ level according to the analysis of variance followed by Scheffe's test for multiple comparisons $(p<0.05)$. Values presented as mean \pm SD. (B-E) The inhibitory effect of BG3 and BG5 on the expression of mRNA of hla, agrA, sea, and seb as analyzed by qRT-PCR. S. aureus ATCC 33591 treated with serial dilutions of BG 3 or 5 for 4 h. Values represent the mean and standard error of three independent experiments. ${ }^{* *} p<0.01$ and ${ }^{* * *} p<0.001$ in comparison with MRSA (control) group. 
$\mathbf{A}$
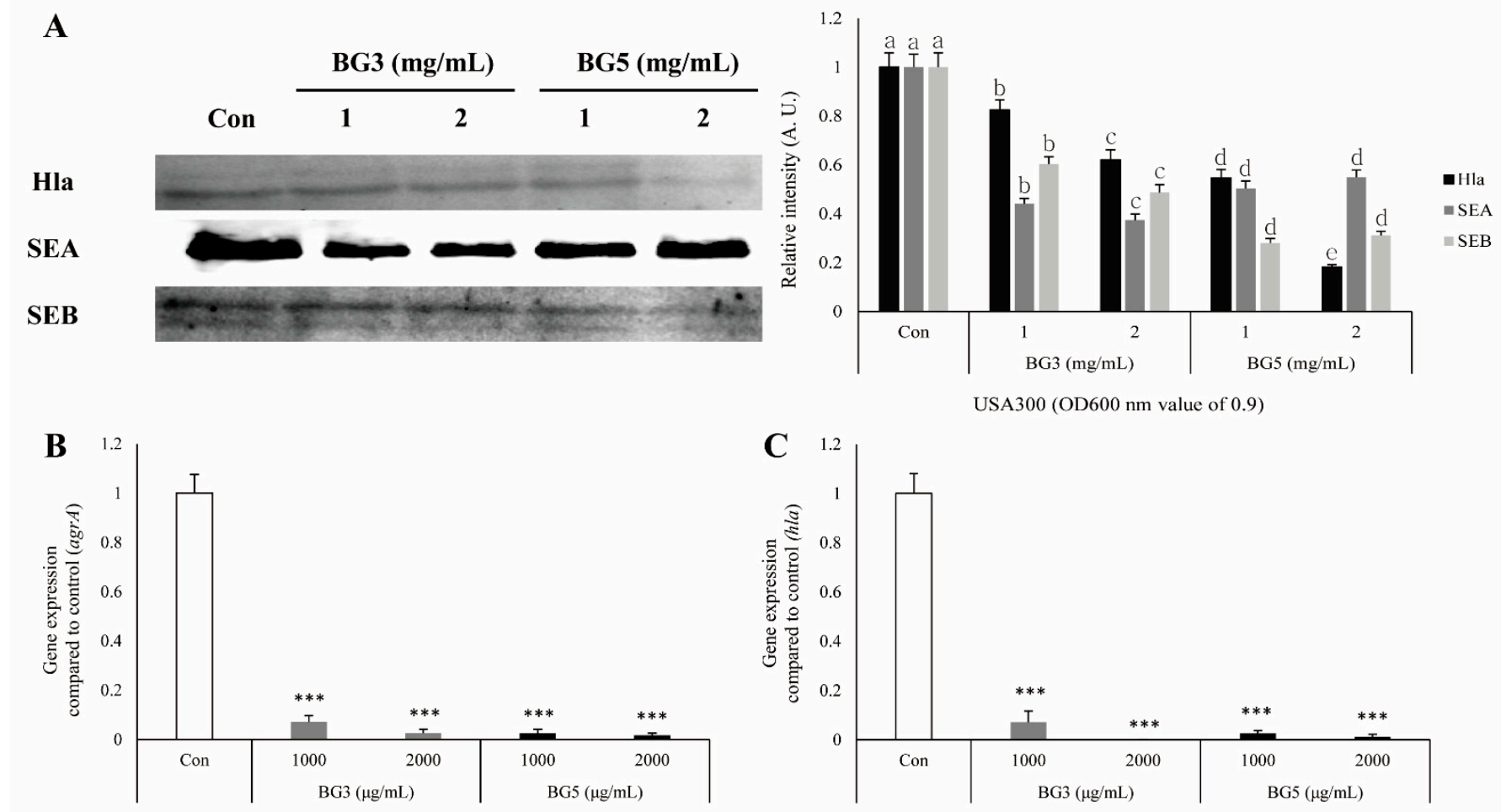

USA300 (OD600 nm value of 0.9$)$
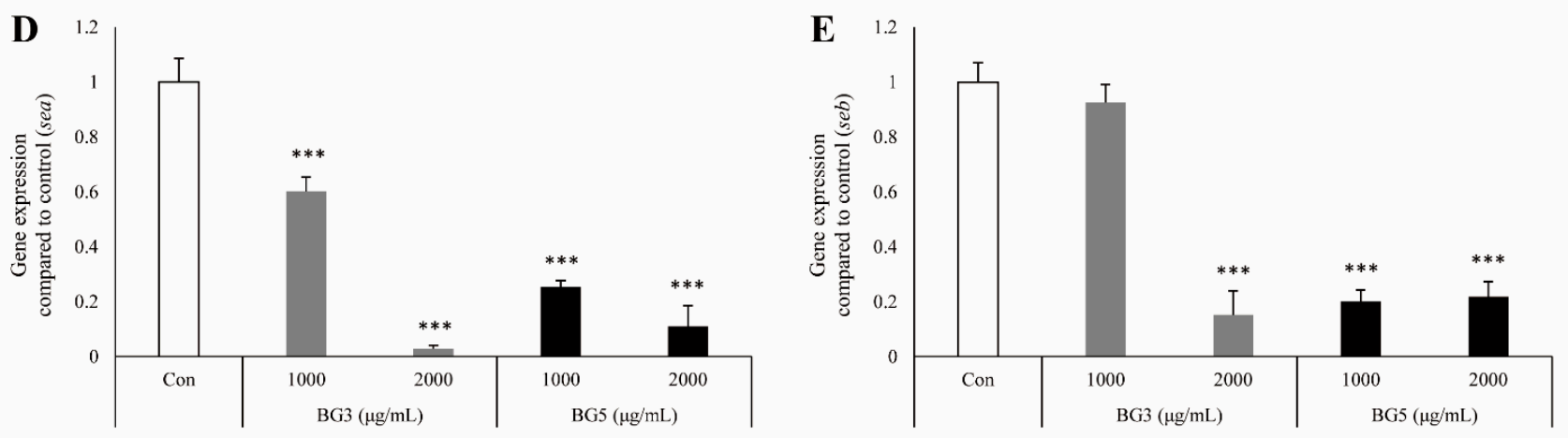

USA300 (OD600 $\mathrm{nm}$ value of 0.9$)$

USA300 (OD600 $\mathrm{nm}$ value of 0.9 )

Figure 5. (A) Inhibitory effects of BG3 and BG5 on $\alpha$-hemolysin (Hla), staphylococcal enterotoxin A (SEA), and staphylococcal enterotoxin B (SEB) production in S. aureus USA300, as analyzed by Western blotting. S. aureus USA300 cells treated with serial dilutions of BG3 or BG5 (1 and $2 \mathrm{mg} / \mathrm{mL}$ ) for $4 \mathrm{~h}$. (a-e) Significant differences at $p<0.05$ level according to the analysis of variance followed by Scheffe's test for multiple comparisons $(p<0.05)$. Values, means \pm standard errors. (B-E) The inhibitory effect of BG3 and BG5 on the expression of mRNA of hla, agrA, sea, and seb as analyzed by qRT-PCR. S. aureus USA300 treated with serial dilutions of BG 3 or 5 for $4 \mathrm{~h}$. Values represent mean and standard error of three independent experiments. ${ }^{* * *} p<0.001$ in comparison with MRSA (control) group.

\section{Discussion}

Ginseng has been widely used in Eastern medicine for thousands of years, and white ginseng, prepared by drying fresh ginseng, is steamed again and dried to produce black and red ginseng. During this process, the ingredients of fresh ginseng are changed, and new physiological ingredients (20(S)-, 20(R)-Rg3, Rk3, Rh4, Rk1, Rg5, etc.) that are not present in fresh ginseng are generated and their content is increased [24]. Generally, white ginseng is manufactured by the dehydration of fresh ginseng using sunlight, and red ginseng is produced by steaming fresh ginseng at $95-100{ }^{\circ} \mathrm{C}$ for a reasonable amount of time [23]. The processing method of BG still requires in-depth research, but it takes at least three more steaming and drying processes than red ginseng does. In detail, when 
processing Radix Rehmanniae in traditional Eastern medicine, the process of steaming and drying is repeated nine times, and this process is modified and used for ginseng. In Korea, this processing method is called kujeung-kupo, meaning that it is steamed nine times and dried nine times. However, a standard process for the production of black ginseng has not yet been established, and this kujeung-kupo process is occasionally found to produce excessive benzopyrene, which was recently classified as a carcinogen [24]. Therefore, the aim of this study was to explore new functionalities that can suppress the toxicity of MRSA while being safe using BG made by a temporary process that repeats the steaming and drying process 3 or 5 times.

MRSA is the most common cause of hospital-associated multidrug-resistant infections, and there is a very high risk of infection in people with impaired immunity, such as weakened immunity, an underlying disease, or a disrupted skin barrier [34]. Moreover, today's MRSA is no longer limited to inpatients or persons with predisposing risk factors, and it is globally reported in diverse community populations [29,35]. CA-MRSA strains are recognized as distinct clonal entities that differ from traditional HA-MRSA strains, and both CA-MRSA and HA-MRSA are resistant to methicillin (and all beta-lactam antibiotics), but with important differences, such as in epidemiology, microbiologic characteristics, clinical aspects of infection, and management [35]. Therefore, it is necessary to understand the antibiotic resistance and virulence factors of bacteria and to develop antibacterial agents with new mechanisms.

Hla, also known as $\alpha$-toxin, is the major cytotoxic agent released by the $S$. aureus bacterium and the first identified member of the pore-forming beta-barrel toxin family [36]. $S$. aureus exoproteins, such as exotoxins and enzymes, convert the host tissue into nutrients for bacterial growth and possess properties including pyrogenicity and superantigenicity [32]. Hla significantly contributes to $S$. aureus-induced cell death and triggers caspase activation via the intrinsic death pathway, independently of death receptor signaling [32,37]. SEs, as superantigens, can result in staphylococcal gastroenteritis, one of the causes of food poisoning in humans [32,38]. SEs secreted by $S$. aureus stimulate cells in the immune system, such as macrophages, to release TNF and other proinflammatory cytokines [39]. Therefore, a TNF- $\alpha$ release assay was carried out to elucidate the biological relevance of the reduction in Hla, SEA, and SEB secretion induced by BG extracts. The secretion of TNF- $\alpha$ in RAW264.7 cells treated with MRSA-culture media was increased, and this response was attenuated by treatment with BG extracts (Figure 3). These results suggest that BG extracts inhibit the activation of immune responses, which are activated by the virulence factors derived from MRSA. It is known that the expression of the hla gene is regulated by the agrA gene. Agr quorum sensing is an important bacterial regulatory system by detecting extracellular autoinducers, and is responsible for regulating the virulence of many bacterial pathogens [14]. It is also associated with an increased expression of virulence genes encoding toxins and degradative exoenzymes, which are essential for the establishment of infection [40-43]. Therefore, we examined the alteration of protein expression of Hla, SEA, and SEB by Western blot analysis, and mRNA expression of agr A, hla, sea, and seb by quantitative reverse-transcription polymerase chain reaction (qRT-PCR), which are important factors in the pathogenicity of MRSA. Treatment with BG extract resulted in the decreased protein expression of Hla, SEA, and SEB in MRSA. In addition, BG extract was shown to decrease agrA, hla, sea, and seb expression in MRSA (Figures 4 and 5).

Therefore, BG strongly reduces the secretion of selected virulence factors produced by S. aureus, suggesting that a BG-based structure may be used for the development of drugs aimed at staphylococcal virulence-related exoproteins.

\section{Materials and Methods}

\subsection{BG Extract Preparation}

In this study, 5-year-old fresh Korean ginseng roots (Chungcheongbuk-do, Republic of Korea) available at the market were used as a sample. The optimal conditions for the preparation of BG were manufactured by 3 (BG3) and 5 (BG5) time repeated steaming of the 
white ginseng at $95-98^{\circ} \mathrm{C}$ for $5 \mathrm{~h}$ in pottery apparatus, followed by drying at $50{ }^{\circ} \mathrm{C}$ for $24 \mathrm{~h}$. The dried BG was pulverized to be fine enough to pass through mesh 80. BG was coarsely ground and extracted twice by reflux extraction with $30 \%$ fermented ethanol at $80{ }^{\circ} \mathrm{C}$ for $4 \mathrm{~h}$. After extraction, extracts were filtered using a filter paper (No. 1, Whatman, Maidstone, UK) and using a decompression distillation apparatus (N-1000, EYELA, Tokyo, Japan). The concentrated extract was obtained using a $-80{ }^{\circ} \mathrm{C}$ ultralow-temperature freezer (DF8520, IlshinBioBase, Dongducheon, Korea) and freeze dryer (FDU-1200, EYELA, Tokyo, Japan).

\subsection{Bacterial Strains and Reagents}

The S. aureus ATCC 33591 strain used in this study was a standard strain of HA-MRSA, and the $S$. aureus USA300 strain is now the dominant CA-MRSA strain in several countries, a major international epidemic clone that causes both community- and hospital-onset infections [44]. S. aureus ATCC 33591 was incubated in brain-heart infusion (BHI), and S. aureus USA300 was incubated in tryptic soy (TS) broth at $37^{\circ} \mathrm{C}$ for $24 \mathrm{~h}$. RAW 264.7 (macrophage, ATCC TIB-71) cells were cultured in an RPMI 1640 medium supplemented with $10 \%$ fetal bovine serum and $100 \mathrm{U} / \mathrm{mL}$ of penicillin/streptomycin sulfate. Cells were cultured in a humidified incubator with $5 \% \mathrm{CO}_{2}$ atmosphere at $37{ }^{\circ} \mathrm{C}$. Primary antibodies, including anti-Staphylococcus alpha hemolysin antibody, rabbit polyclonal antiStaphylococcus enterotoxin A antibody, and rabbit polyclonal anti-Staphylococcus enterotoxin $B$ antibody were purchased from Abcam (Cambridge, UK). In addition, anti-rabbit IgG and goat anti-mouse IgG secondary antibodies were obtained from Thermo Scientific (Wilmington, DE, USA).

\subsection{Measurement of Minimum Inhibitory Concentration, and Bacterial Growth Curve Assay}

Serial twofold dilutions of BG extracts were prepared in $100 \mu \mathrm{L}$ of BHI and TS broth in 96-well microplates. Microplates were inoculated with MRSA adjusted to a 0.5 McFarland standard (approximately $10 \mu \mathrm{L}$ of $1.5 \times 10^{8}$ colony-forming units (CFU)/mL; final density, $1.5 \times 10^{6} \mathrm{CFU} / \mathrm{mL}$ ). The MIC was determined as the lowest BG concentration suppressing the growth of MRSA after $24 \mathrm{~h}$ of incubation at $37^{\circ} \mathrm{C}$. Bacterial cells were harvested at an early log phase $\left(\mathrm{OD}_{600}=0.5\right)$ and resuspended in phosphate-buffered saline $(\mathrm{PBS})$ at $\sim 10^{8}$ to $10^{9} \mathrm{CFU} / \mathrm{mL}$. Subsequently, bacterial samples were incubated with $1 / 2 \mathrm{MIC}$ of BG at different intervals up to $24 \mathrm{~h}$ at $37^{\circ} \mathrm{C}$. After incubation, bacterial samples were applied on the surface of TS agar plates. After $16 \mathrm{~h}$ of incubation at $37^{\circ} \mathrm{C}$, the surviving bacterial cells were counted.

\subsection{Western Blot Analysis}

The proteins of Hla, SEA, and SEB were detected by a Western blot analysis. The detailed procedures are carried out based on the previously reported investigation [27]. Briefly, MRSA strain S. aureus ATCC 33591 or USA300 was grown to an OD 600 value of 0.9 in BHI or TS broth with various concentrations of BG, and the bacterial cells were prepared with SMART ${ }^{\mathrm{TM}}$ bacterial protein-extraction solution (iNtRON Biotechnology) according to the manufacturer's protocol. $20 \mu \mathrm{L}$ of protein lysates were separated by $12 \%$ sodium dodecyl sulfate polyacrylamide gel electrophoresis (SDS-PAGE), and the resolved proteins were transferred onto polyvinylidene difluoride membranes. The membrane was blocked with 5\% skimmed milk and sequentially incubated with the primary antibodies (1:500) and secondary antibodies (1:2500). Immunoreactive protein bands were detected using the EzWestLumi Plus luminol substrate (ATTO Co., Tokyo, Japan), and visualized using an ImageQuant LAS 4000 mini chemical luminescent imager (GE Healthcare Korea, Seoul, Korea).

\subsection{Tumor Necrosis Factor- $\alpha$ Enzyme-Linked Immunosorbent Assay (ELISA)}

The detailed procedures for this assay are carried out based on the previously reported investigation [27]. Briefly, the MRSA was grown to an $\mathrm{OD}_{600}$ value of 0.9 in MuellerHinton $(\mathrm{MH})$ broth with various concentrations of BG extract. After $4 \mathrm{~h}$ incubation, the 
supernatants were collected by filtering through a $0.2 \mu \mathrm{m}$ filter. RAW 264.7 cells were seeded at a density of $10^{6} / \mathrm{mL}$ in RPMI, dispensed $(100 \mu \mathrm{L})$ into 96 well tissue culture plates, and incubated in $5 \% \mathrm{CO}_{2}$ at $37{ }^{\circ} \mathrm{C}$ in an incubator for $18 \mathrm{~h}$ to allow for adherence. After cell culture media were washed, the RPMI 1640 medium $(150 \mu \mathrm{L})$ and the supernatants of the strain (S. aureus ATCC 33591 and USA300,50 $\mu \mathrm{L}$ ) were added to the tissue culture plate. After incubation for $16 \mathrm{~h}$, the culture media were collected to determine the levels of TNF- $\alpha$ present in each sample using the ELISA kit from OptEIA ${ }^{\mathrm{TM}}$ human enzymelinked immunosorbent assay (ELISA; BD Bioscience, San Jose, CA, USA) according to the manufacturer's instruction.

\subsection{RNA Extraction and Quantitative Reverse-Transcription-Polymerase Chain Reaction (qRT-PCR)}

Total RNA was isolated from S. aureus ATCC 33591 or USA300 using an E.Z.N.A. ${ }^{\circledR}$ bacterial RNA kit (Omega Bio-tek, Norcross, GA, USA) according to the manufacturer's instructions. Total RNA was dissolved in diethyl pyrocarbonate-treated distilled water. The concentration of RNA was determined by measuring the absorbance ratio at 260 and $280 \mathrm{~nm}$ on a spectrophotometer (BioTek, Winooski, VT, USA). Complementary DNA was synthesized using the QuantiTect reverse transcription kit (Qiagen, Seoul, Korea) according to the manufacturer's instructions. The sequences of the primers used in this experiment are listed in Table 1 . The reaction was performed in triplicate using a Power SYBR ${ }^{\circledR}$ Green PCR master mix (Applied Biosystems, Foster City, CA, USA) and a StepOnePlus real-time PCR system (Applied Biosystems). The data were analyzed and the expression levels of target genes relative to the endogenous reference gene, 16S rRNA, were calculated by the delta-delta cycle threshold method, and the data were analyzed using StepOne software (Applied Biosystems).

Table 1. Primer sequences for real-time RT-PCR.

\begin{tabular}{|c|c|c|}
\hline \multirow{2}{*}{ Target Genes } & \multicolumn{2}{|c|}{ Primer Sequences $\left(5^{\prime}-3^{\prime}\right)$} \\
\hline & Forward Primer & Reverse Primer \\
\hline hla & TTGGTGCAAATGTTTC & TCACTTTCCAGCCTACT \\
\hline sea & ATGGTGCTTATTATGGTTATC & ATGGTGCTTATTATGGTTATC \\
\hline$s e b$ & TGTTCGGGTATTTGAAGATGG & CGTTTCATAAGGCGAGTTGTT \\
\hline $\operatorname{agr} A$ & TGATAATCCTTATGAGGTGC & CACTGTGACTCGTAACGAAA \\
\hline 16 s rRNA & CGTGCTACAATGGACAATAC & ATCTACGATTACTAGCGATT \\
\hline
\end{tabular}

\subsection{Statistical Analysis}

All results are presented as mean \pm standard error of three independent experiments. Statistical analysis was performed with GraphPad Prism software, version 4 (GraphPad Software Inc., San Diego, CA, USA). Tukey's multiple-comparison test was applied for statistically significant differences between mean values $(p<0.05)$. The TNF- $\alpha$ levels of statistical analysis were established by Scheffe's test (SPSS. ver.23) for multiple comparisons. $p$ values $<0.05$ were considered significant.

\section{Conclusions}

In the present study, we analyzed changes in antivirulence activities depending on the number of rounds of steaming and drying for Korean ginseng. BG extracts showed weak antibacterial activity with high MIC values against MRSA strains. However, the treatment with BG extracts inhibited the protein and mRNA expression of virulent factors including Hla, SEA, SEB, and agrA against MRSA strains. These results suggest that it may be a candidate for treatment or a combination of MRSA infection. We next plan to study the mechanism of this activity and various physiological activities of BG. 
Author Contributions: Conceptualization, Y.-S.L. and D.Y.L.; methodology, Y.-S.L.; analysis K.-W.K.; resources, D.Y.L.; data curation, O.-H.K.; writing—original-draft preparation, Y.-S.L.; writing一review, D.Y.L.; editing, D.Y.; supervision, D.-Y.K.; funding acquisition, G.-S.K. All authors have read and agreed to the published version of the manuscript.

Funding: This work was carried out with the support of the Cooperative Research Program for Agricultural Science and Technology Development (project no. PJ01497501), Rural Development Administration, Republic of Korea.

Data Availability Statement: No new data were created or analyzed in this study. Data sharing is not applicable to this article.

Conflicts of Interest: The authors declare no conflict of interest. The founding sponsors had no role in the design of the study; collection, analyses, or interpretation of the data; writing of the manuscript; or decision to publish the results.

\section{References}

1. Uemura, E.; Kakinohana, S.; Higa, N.; Toma, C.; Nakasone, N. Comparative chracterization of Staphylococcus aureus isolates from throats and noses of healthy volunteers. Jpn. J. Infect. Dis. 2004, 57, 21-24.

2. Sakr, A.; Brégeon, F.; Mège, J.-L.; Rolain, J.-M.; Blin, O. Staphylococcus aureus Nasal Colonization: An Update on Mechanisms, Epidemiology, Risk Factors, and Subsequent Infections. Front. Microbiol. 2018, 9, 2419. [CrossRef] [PubMed]

3. Wu, S.; Liu, Y.; Zhang, H.; Lei, L. The Pathogenicity and Transcriptome Analysis of Methicillin-Resistant Staphylococcus Aureus in Response to Water Extract of Galla Chinensis. Evid. Based Complement. Alternat. Med. 2019, 2019, 3276156. [CrossRef] [PubMed]

4. Ventola, C.L. The Antibiotic Resistance Crisis: Part 1: Causes and Threats. Pharm. Ther. 2015, 40, $277-283$.

5. Saidi, N.; Owlia, P.; Marashi, S.M.A.; Saderi, H. Inhibitory effect of probiotic yeast Saccharomyces cerevisiae on biofilm formation and expression of $\alpha$-hemolysin and enterotoxin A genes of Staphylococcus aureus. Iran. J. Microbiol. 2019, 11, 246-254. [CrossRef] [PubMed]

6. Diep, B.A.; Le, V.T.M.; Visram, Z.C.; Rouha, H.; Stulik, L.; Dip, E.C.; Nagy, G.; Nagy, E. Improved Protection in a Rabbit Model of Community-Associated Methicillin-Resistant Staphylococcus aureus Necrotizing Pneumonia upon Neutralization of Leukocidins in Addition to Alpha-Hemolysin. Antimicrob. Agents Chemother. 2016, 60, 6333-6340. [CrossRef]

7. Seilie, E.S.; Bubeck Wardenburg, J. Staphylococcus aureus pore-forming toxins: The interface of pathogen and host complexity. Semin. Cell Dev. Biol. 2017, 72, 101-116. [CrossRef]

8. Vandenesch, F.; Lina, G.; Henry, T. Staphylococcus aureus hemolysins, bi-component leukocidins, and cytolytic peptides: A redundant arsenal of membrane-damaging virulence factors? Front. Cell. Inf. Microbiol. 2012, 2, 12. [CrossRef]

9. Qiu, J.; Wang, D.; Xiang, H.; Feng, H.; Jiang, Y.; Xia, L.; Dong, J.; Lu, J.; Yu, L.; Deng, X. Subinhibitory concentrations of thymol reduce enterotoxins A and B and alpha-hemolysin production in Staphylococcus aureus isolates. PLoS ONE 2010, 5, e9736. [CrossRef]

10. Argudín, M.Á.; Mendoza, M.C.; Rodicio, M.R. Food poisoning and Staphylococcus aureus enterotoxins. Toxins 2010, 2, 1751-1773. [CrossRef]

11. Rusnak, J.M.; Kortepeter, M.; Ulrich, R.; Poli, M.; Boudreau, E. Laboratory Exposures to Staphylococcal Enterotoxin B. Emerg. Infect. Dis. 2004, 10, 1544-1549. [CrossRef]

12. Pinchuk, I.V.; Beswick, E.J.; Reyes, V.E. Staphylococcal Enterotoxins. Toxins 2010, 2, 2177-2197. [CrossRef] [PubMed]

13. Cosgriff, C.J.; White, C.R.; Teoh, W.P.; Grayczyk, J.P.; Alonzo, F. Control of Staphylococcus aureus Quorum Sensing by a MembraneEmbedded Peptidase. Infect. Immun. 2019, 87, e00019-19. [CrossRef]

14. Kong, R.; Lee, Y.-S.; Kang, D.-H.; Wang, S.; Li, Q.; Kwon, D.-Y.; Kang, O.-H. The antibacterial activity and toxin production control of bee venom in mouse MRSA pneumonia model. BMC Complement. Med. Ther. 2020, 20, 238. [CrossRef]

15. Zuo, G.-Y.; Zhang, X.-J.; Yang, C.-X.; Han, J.; Wang, G.-C.; Bian, Z.-Q. Evaluation of traditional Chinese medicinal plants for anti-MRSA activity with reference to the treatment record of infectious diseases. Molecules 2012, 17, 2955-2967. [CrossRef]

16. Hemaiswarya, S.; Kruthiventi, A.K.; Doble, M. Synergism between Natural Products and Antibiotics against Infectious Diseases. Phytomedicine 2008, 15, 639-652. [CrossRef]

17. Ha, Y.W.; Lim, S.S.; Ha, I.J.; Na, Y.-C.; Seo, J.-J.; Shin, H.; Son, S.H.; Kim, Y.S. Preparative isolation of four ginsenosides from Korean red ginseng (steam-treated Panax ginseng C. A. Meyer), by high-speed counter-current chromatography coupled with evaporative light scattering detection. J. Chromatogr. A 2007, 1151, 37-44. [CrossRef] [PubMed]

18. Kachur, K.; Suntres, Z.E. The antimicrobial properties of ginseng and ginseng extracts. Expert Rev. Anti Infect. Ther. 2016, 14, 81-94. [CrossRef] [PubMed]

19. Zhu, L.; Luan, X.; Dou, D.; Huang, L. Comparative Analysis of Ginsenosides and Oligosaccharides in White Ginseng (WG), Red Ginseng (RG) and Black Ginseng (BG). J. Chromatogr. Sci. 2019, 57, 403-410. [CrossRef]

20. Kim, Y.-R.; Yang, C.-S. Protective roles of ginseng against bacterial infection. Microb. Cell 2018, 5, 472-481. [CrossRef] [PubMed]

21. Park, I.H.; Han, S.B.; Kim, J.M.; Piao, L.; Kwon, S.W.; Kim, N.Y.; Kang, T.L.; Park, M.K.; Park, J.H. Four new acetylated ginsenosides from processed ginseng (sun ginseng). Arch. Pharm. Res. 2002, 25, 837-841. [CrossRef] 
22. Nam, K.-Y.; Lee, N.-R.; Moon, B.-D.; Song, G.-Y.; Shin, H.-S.; Choi, J.-E. Changes of Ginsenosides and Color from Black Ginsengs Prepared by Steaming-Drying Cycles. Korean J. Med. Crop Sci. 2012, 20, 27-35. [CrossRef]

23. Jin, Y.; Kim, Y.-J.; Jeon, J.-N.; Wang, C.; Min, J.-W.; Noh, H.-Y.; Yang, D.-C. Effect of white, red and black ginseng on physicochemical properties and ginsenosides. Plant Foods Hum. Nutr. 2015, 70, 141-145. [CrossRef]

24. Ban, Y.-J. Optimization of the Manufacturing Process for Black Ginseng. J. Korean Soc. Appl. Biol. Chem. 2009, 53, 71-77. [CrossRef]

25. Park, S.-J.; Park, M.; Sharma, A.; Kim, K.; Lee, H.-J. Black Ginseng and Ginsenoside Rb1 Promote Browning by Inducing UCP1 Expression in 3T3-L1 and Primary White Adipocytes. Nutrients 2019, 11, 2747. [CrossRef] [PubMed]

26. Metwaly, A.M.; Lianlian, Z.; Luqi, H.; Deqiang, D. Black Ginseng and Its Saponins: Preparation, Phytochemistry and Pharmacological Effects. Molecules 2019, 24, 1856. [CrossRef] [PubMed]

27. Youn, U.J.; Gu, B.-S.; Kim, K.H.; Ha, C.; Jung, I.C. Variation of main components according to the number of steaming and drying of Rehmanniae radix preparata. J. Pharmacopunct. 2018, 21, 112-119.

28. Lee, D.Y.; Kim, M.-J.; Yoon, D.; Lee, Y.-S.; Kim, G.-S.; Yoo, Y.C. Ginseng Berry Prevents Alcohol-Induced Liver Damage by Improving the Anti-Inflammatory System Damage in Mice and Quality Control of Active Compounds. Int. J. Mol. Sci. 2019, 20, 3522. [CrossRef]

29. Cheung, G.Y.C.; Wang, R.; Khan, B.A.; Sturdevant, D.E.; Otto, M. Role of the accessory gene regulator agr in community-associated methicillin-resistant Staphylococcus aureus pathogenesis. Infect. Immun. 2011, 79, 1927-1935. [CrossRef]

30. Choi, J.H.; Jang, A.Y.; Lin, S.; Lim, S.; Kim, D.; Park, K.; Han, S.-M.; Yeo, J.-H.; Seo, H.S. Melittin, a Honeybee venom-derived antimicrobial peptide, may target methicillin-resistant Staphylococcus aureus. Mol. Med. Rep. 2015, 12, 6483-6490. [CrossRef]

31. Mun, S.-H.; Kong, R.; Seo, Y.-S.; Zhou, T.; Kang, O.-H.; Shin, D.-W.; Kwon, D.-Y. Subinhibitory concentrations of punicalagin reduces expression of virulence-related exoproteins by Staphylococcus aureus. FEMS Microbiol. Lett. 2016, 363, fnw253. [CrossRef] [PubMed]

32. Qiu, J.; Wang, J.; Luo, H.; Du, X.; Li, H.; Luo, M.; Dong, J.; Chen, Z.; Deng, X. The effects of subinhibitory concentrations of costus oil on virulence factor production in Staphylococcus aureus. J. Appl. Microbiol. 2011, 110, 333-340. [CrossRef] [PubMed]

33. Pontzer, C.H.; Russell, J.K.; Johnson, H.M. Localization of an Immune Functional Site on Staphylococcal Enterotoxin A Using the Synthetic Peptide Approach. J. Immunol. 1989, 143, 280-284. [PubMed]

34. Lindsay, J.A. Hospital-associated MRSA and antibiotic resistance-what have we learned from genomics? Int. J. Med. Microbiol. 2013, 303, 318-323. [CrossRef]

35. Bukharie, H. A review of community-acquired methicillin-resistant Staphylococcus aureus for primary care physicians. J. Fam. Community Med. 2010, 17, 117-120. [CrossRef]

36. Bhakdi, S.; Tranum-Jensen, J. Alpha-toxin of Staphylococcus aureus. Microbiol. Rev. 1991, 55, 733-751. [CrossRef]

37. Bantel, H.; Sinha, B.; Domschke, W.; Peters, G.; Schulze-Osthoff, K.; Jänicke, R.U. alpha-Toxin is a mediator of Staphylococcus aureusinduced cell death and activates caspases via the intrinsic death pathway independently of death receptor signaling. J. Cell Biol. 2001, 155, 637-648. [CrossRef]

38. Leng, B.-F.; Qiu, J.-Z.; Dai, X.-H.; Dong, J.; Wang, J.-F.; Luo, M.-J.; Li, H.-E.; Niu, X.-D.; Zhang, Y.; Ai, Y.-X.; et al. Allicin reduces the production of $\alpha$-toxin by Staphylococcus aureus. Molecules 2011, 16, 7958-7968. [CrossRef] [PubMed]

39. Shi, C.; Zhao, X.; Li, W.; Meng, R.; Liu, Z.; Liu, M.; Guo, N.; Yu, L. Inhibitory effect of totarol on exotoxin proteins hemolysin and enterotoxins secreted by Staphylococcus aureus. World J. Microbiol. Biotechnol. 2015, 31, 1565-1573. [CrossRef]

40. Qiu, J.; Zhang, X.; Luo, M.; Li, H.; Dong, J.; Wang, J.; Leng, B.; Wang, X.; Feng, H.; Ren, W.; et al. Subinhibitory concentrations of perilla oil affect the expression of secreted virulence factor genes in Staphylococcus aureus. PLoS ONE 2011, 6, e16160. [CrossRef]

41. Kim, E.-S.; Kang, S.-Y.; Kim, Y.-H.; Lee, Y.-E.; Choi, N.-Y.; You, Y.-O.; Kim, K.-J. Chamaecyparis obtusa Essential Oil Inhibits Methicillin-Resistant Staphylococcus aureus Biofilm Formation and Expression of Virulence Factors. J. Med. Food 2015, 18, 810-817. [CrossRef] [PubMed]

42. Zhang, H.; Zheng, Y.; Gao, H.; Xu, P.; Wang, M.; Li, A.; Miao, M.; Xie, X.; Deng, Y.; Zhou, H.; et al. Identification and Characterization of Staphylococcus aureus Strains with an Incomplete Hemolytic Phenotype. Front. Cell Infect. Microbiol. 2016, 6, 146. [CrossRef] [PubMed]

43. Da, F.; Yao, L.; Su, Z.; Hou, Z.; Li, Z.; Xue, X.; Meng, J.; Luo, X. Antisense locked nucleic acids targeting agrA inhibit quorum sensing and pathogenesis of community-associated methicillin-resistant Staphylococcus aureus. J. Appl. Microbiol. 2017, 122, 257-267. [CrossRef] [PubMed]

44. Nimmo, G.R. USA300 abroad: Global spread of a virulent strain of community-associated methicillin-resistant Staphylococcus aureus. Clin. Microbiol. Infect. 2012, 18, 725-734. [CrossRef] [PubMed] 